\title{
Phenolic compound derived from microwave- assisted pyrolysis of coconut shell: Isolation and antibacterial activity testing
}

\author{
Dwi Nuryana ${ }^{1}$, Muhammad Fahrul Rahman Alim ${ }^{1}$, Rendy Okta Loveyanto ${ }^{1}$, Bayu Adi \\ Wibowo $^{1}$, Raja Safazliana Binti Raja Sulong ${ }^{2}$, Mohd Amir Asyraf Mohd Hamzah², \\ Zainul Akmar Zakaria ${ }^{2}$, and Ratna Dewi Kusumaningtyas ${ }^{1^{*}}$ \\ ${ }^{1}$ Chemical Engineering Department, Faculty of Engineering, Universitas Negeri Semarang, 50229 \\ Gunungpati, Semarang, Indonesia \\ ${ }^{2}$ School of Chemical and Energy Engineering (FCEE), Faculty of Engineering, Universiti Teknologi \\ Malaysia (UTM) 81310 Skudai, Johor Bahru, Malaysia
}

\begin{abstract}
Indonesia is rich in natural resources, coconut plantation being one of them. The coconut processing industry produces coconut shell (CS) waste. The most effective technique to increase the value of this waste is to convert CS biomass through pyrolysis process. This research focuses on intensification of conversion process of CS by Microwave-Assisted Pyrolysis (MAP) to obtain PA. PA contains phenolic compounds which have antibacterial properties so they can be formulated as an antibacterial agent. CS has moisture and ash content of $8.89 \%$ and $0.21 \%$, respectively. PA was produced from the MAP of CS at $600 \mathrm{~W}$ at $450^{\circ} \mathrm{C}$ and $500^{\circ} \mathrm{C}$ for 10,20 , and 30 minutes. The PA was extracted using ethyl acetate to obtain phenolic contents. Optimum pyrolysis condition was found at $400^{\circ} \mathrm{C}$ for 30 minutes and yield of PA was determined at $32.20 \mathrm{~g}$ with total phenolic content (TPC) of $112.13 \mathrm{mg} \mathrm{GAE} / \mathrm{g}$. The inhibition zone of phenolic extract from coconut shell (PECS) using E. Coli was determined within 22$25 \mathrm{~mm}$ that quantitatively PECS can effectively kill bacteria. PECS by MAP and its aplication as an antibacterial agent has never been performed, so this work is an important contribution in the intensification of pyrolysis and in medical field.
\end{abstract}

Keyword: Antibacterial agent, Biomass, Microwave-assisted Pyrolysis, Phenolic compounds

\footnotetext{
*Corresponding author: ratnadewi.kusumaningtyas@mail.unnes.ac.id
} 


\section{Introduction}

Indonesia is the second largest coconut producing country in ASEAN after Philippines [1]. The total area of Indonesian coconut plantations in 2018 reached 3.547 million hectares with a total production of 2.866 million tons. The development of coconut production in Indonesia had tendency to increase by $1.95 \%$ per year in $1980-2018$ period [2]. The high demand for processed coconut exports has resulted in increased waste in the form of coirs and coconut shells (CS). A coconut produces 30\% fiber while $15 \%-19 \%$ of the total weight is the weight of the CS [3]. Even as organic waste, the CS cannot decompose quickly in the environment. Therefore, the amount of the waste continues to increase along with the increase in processed coconut products. One of the ways to utilize CS into available products is thermochemical conversion which is pyrolysis. Products of the pyrolysis process include charcoal, tar, gas and pyroligneous acid (PA) [4]. PA is smoke from the pyrolysis process which is condensed into a liquid product consisting of water, alcohol, organic acids, phenols, aldehydes, ketones, esters, furans, pyran derivatives, hydrocarbons, and nitrogen compounds [5]. PA compounds have antibacterial, anti-oxidant and anti-inflammatory properties that are prospective to be utilized for medicinal and pharmaceutical products formulations [6].

Based on its composition, the CS is composed of 3 main components: $26.60 \%$ of cellulose, $27.70 \%$ of hemicellulose, and $29.40 \%$ of lignin [7]. The hemicellulose compound can be degraded at temperatures of $200^{\circ} \mathrm{C}-260^{\circ} \mathrm{C}$, cellulose at $240^{\circ} \mathrm{C}-350^{\circ} \mathrm{C}$, while lignin at $280^{\circ} \mathrm{C}-500^{\circ} \mathrm{C}$ [8]. High cellulose and hemicellulose content contribute to higher bio-oil yields, while high lignin content increases biochar yield [9]. Although lignin has a high level of resistance to thermal degradation, decomposition of lignin compounds produces charcoal, carboxylic acids, methanol, phenols and other aromatic compounds in liquid products [10]. Therefore, the high lignin content in a material can produce high phenolic compounds.

Pyrolysis consists of two processes: slow pyrolysis and fast pyrolysis. Slow pyrolysis is a slow process of thermal degradation of organic components in biomass due to the absence of oxygen to a final temperature of approximately $500^{\circ} \mathrm{C}$ [8]. Fast pyrolysis is a process of pyrolysis using high temperature where raw materials are heated quickly in the absence of air so as to produce vapor and dark brown liquids. This process is more sophisticated and can be carefully controlled to provide high yields on liquid products [11]. Previous researches with these following raw materials have been conducted include slow pyrolysis walnut shells to produce activated charcoal [12], produce PA from palm kernel shell [13] and Rosmarinus officinalis leaves [14], produce activated charcoals form rice husk [15], and produce liquid smoke from young coconut, bamboo and durian rind [16]. This research was conducted using conventional thermal heating with an external heater such as a furnace or hot mantle. This heating system is relatively slow and inefficient. Therefore, intensification of the process was carried out. Therefore, the pyrolysis could go more quickly and saved energy by using Microwave-Assisted Pyrolysis (MAP). Research using MAP has been carried out on several biomass such as oil palm fiber to make hydrogen gas [17] and pyrolysis liquid oil [18], palm kernel shell to produce anti - bacterial agent [19] and bio-oil [20], characterization of empty fruit bunch for MAP [21], and pineapple waste to produce PA [22]. However, from a number of previous studies, there have not been any studies found on the application of MAP to CS aimed at utilizing PA as an antibacterial agent.

MAP was developed as an alternative heating source in the pyrolysis process. Volumetric heating properties and better control and uniform heat distribution can be achieved through heating on MAP [23]. MAP can prevent the formation of secondary reactions thereby increasing the quality of the products. MAP technology has the potential 
to save energy and reduce process costs. In producing PA, MAP is influenced by several factors including the type of reactor, particle size, pressure, temperature, power level, residence time, flow carrier gas and the use of activated carbon [24]. Therefore, this research investigated the effect of changes in time and temperature in the MAP process to determine the feasible conditions for producing the most PA.

One of the interesting benefits of PA to be investigated is its antibacterial properties. Therefore, the extracts of phenolic compounds in this study were tested on Escherichia coli bacteria. In previous studies, PA as the result of the CS MAP process had not been tested as an antibacterial agent. Therefore, this study contributes to the effect of MAP operating conditions on PA products and testing phenolic extracts from coconut shell (PECS) from the results of MAP as an antibacterial agent that can be utilized in the medical field. Specifically, the purpose of this study was to determine the effect of time and temperature on PA production in MAP as well as the characteristics of phenolic extracts as an antibacterial agent.

\section{Methodology}

\subsection{Materials}

The materials used in this study included 1) CS from Cococs nucifera originating from Bantul, Indonesia; 2) commercial activated carbon granule (C1452-32112392) from HmBG Chemicals, Malaysia; 3) nitrogen gas; 4) ethyl acetate (EA) (99.5\%, grade AR); 5) Whatman no. 4 filter paper; 6) rotary evaporator (Heidolph, Germany); 7) UV-Vis spectrophotometer (Shimadzu, Japan).

\subsection{Methods}

\subsubsection{Pre-treatment}

CS was cleaned of fiber and dirt, then dried in the sun for 7 days. CS has been dried was subsequently reduced in size by using a hammer mill. Then sieving process was performed so that the same size approximately $1-1.18 \mathrm{~mm}$ was obtained. The small size CS was stored in a place protected from humidity. Based on the raw material test, the CS used for PA production in this study had water content of $8.89 \%$ and ash content of $0.21 \%$.

\subsubsection{Microwave-assisted Pyrolysis (MAP)}

Microwave-assisted pyrolysis (MAP) was carried out referring to a study conducted by Abas [18] with modification of raw material size of $1-1.18 \mathrm{~mm} .100 \mathrm{~g}$ materials and $50 \mathrm{~g}$ of activated carbon were dried at $105^{\circ} \mathrm{C}$ for 24 hours. Furthermore, both were put into a reactor made of quartz glass. Thermocouple type-R was mounted on the reactor and connected to the Picolog Data Logger System (PicoLog Recorder software, version 5.23.0) to show changes in temperature during the reaction. Nitrogen gas was flowed at $2 \mathrm{~L} / \mathrm{min}$, supplied from the top of the reactor for 15 minutes before the pyrolysis process was conducted. Other modifications were the power output on the microwave of $600 \mathrm{~W}$. Pyrolysis temperature was controlled at $400^{\circ} \mathrm{C}$ and $450^{\circ} \mathrm{C}$, while cooling water was set at $6^{\circ} \mathrm{C}$ for the condensation process. The residence time of the MAP process was carried out in 10, 20 and 30 minutes. Liquid and gaseous products went through the condenser column and was collected in a round bottom flask (at the bottom of the condenser) as a mixture of 
PA and bio-oil, while the uncondensed gas was discharged into the environment. Biochar formed in the reactor was called a solid product. The end of this process was to determine the percentage of solid, liquid, and gases product based on the mass of each product.

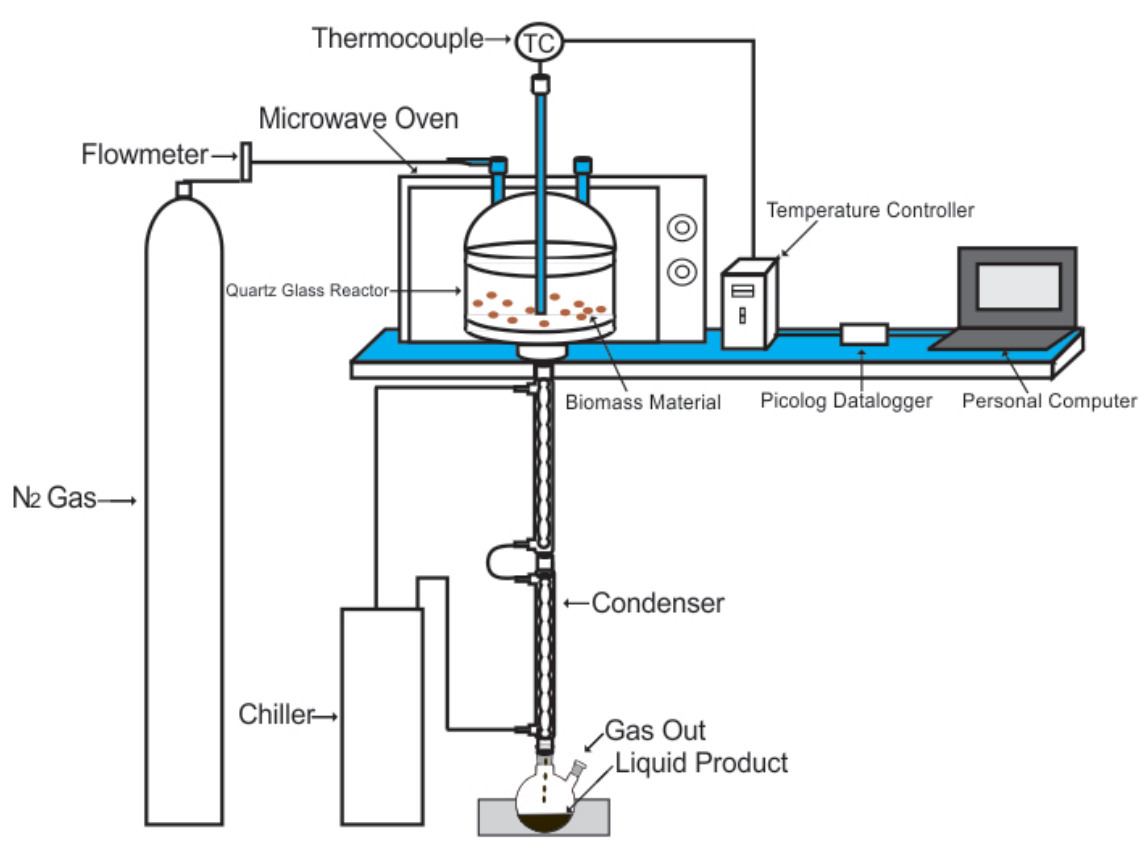

Fig. 1. Microwave-Assisted Pyrolysis

\subsubsection{Purification using Extraction Process}

Pyroligneous acid (PA) is obtained from the liquid product from the pyrolysis process. The liquid product was filtered using Whatman no. 4 filter paper to separate PA from bio oil and other impurities. Ethyl acetate (EA) solvent was added to the PA referring to the research conducted by Loo et al. [25], with these following modifications: PA was extracted using EA at a ratio of 1: 1 using a $100 \mathrm{~mL}$ separatory funnel, was shaken for 3 minutes at room temperature and let it stand for 30 minutes to form two layers. The upper layer was collected as an organic layer and the lower layer as a mixture layer was extracted for the second time using fresh EA. The extracted PA was concentrated using a rotary evaporator (Heidolph, Germany) at a pressure of $120 \mathrm{mBar}$ and a temperature of $80^{\circ} \mathrm{C}$ to $1 / 3$ of the initial volume. Then phenolic extract from coconut shell (PECS) was stored in a desiccator.

\subsubsection{Total Phenolic Content (TPC)}

Total phenolic content (TPC) was determined by using the Folin Ciocalteu reagent as was performed by Ma et al. [4], Gallic acid at a concentration of $10-100 \mu \mathrm{g} / \mathrm{mL}$ was used as the standard reference for making calibration curves. Each sample of $1 \mathrm{~mL}(100 \mu \mathrm{g} / \mathrm{mL})$ was mixed with $1 \mathrm{~mL}$ of $50 \%(\mathrm{v} / \mathrm{v})$ of Folin-Ciocalteu phenol reagent in the test tube. The mixture was shaken for 30 seconds and left at room temperature for 2 minutes. After 2 minutes, $1 \mathrm{~mL}$ of sodium carbonate $\left(\mathrm{Na}_{2} \mathrm{CO}_{3}\right)$ solution was added to neutralize the mixture. The mixture was shaken for 10 seconds and allowed to stand in a dark place for 2 hours at room temperature. Tests were carried out in a dark room because the reagent was sensitive 
to light and to reduce UV interference from redox reactions. Measurement of absorbance of a blue mixture was recorded at $765 \mathrm{~nm}$ using a UV-Vis spectrophotometer (Shimadzu, Japan). Results were reported as averages expressed as micrograms of gallic acid equivalents (GAE) per milligram of sample ( $\mu \mathrm{g} \mathrm{GAE} / \mathrm{mg})$

The TPC concentration was calculated as suggested by Abdelhady et al. [26], as follow:

$$
\text { Total phenolic content (TPC), } \frac{\mathrm{mg} \mathrm{GAE}}{\mathrm{g}}=\frac{C \times V}{M}
$$

Where:

$C=$ concentration of Gallic acid established from the calibration curve in $\mathrm{mg} / \mathrm{ml}$

$V=$ the volume used during assay in $\mathrm{mL}$

$M=$ mass of the extract used during assay in $\mathrm{g}$

\subsubsection{Application as Antibacterial Agent}

The antibacterial test was conducted by the Central Laboratory of Health and Testing of Medical Apparatus in Central Java. The bacteria used for testing was Escherichia coli with the disk diffusion method. The reaction was the formation of a clear zone around the phenolic compound, then the diameter of the clear zone was generated to determine the antibacterial strength.

\section{Results and discussion}

\subsection{MAP Process}

The study intended to investigate the relationship between product yield (solid, liquid and gases) with much emphasis on the PA product (liquid), residence time, and temperature. In this work, the pyrolysis process was conducted in different operation condition, in which its sample was mentioned as S1 to S6 as detected in Table 1. The percentage of product yield of MAP were calculated as weight percent (wt \%) with initial CS of 100 gram.

Table 1. Comparison of MAP product yield for various operation condition

\begin{tabular}{lccccc}
\hline Symbols & Temp $\left({ }^{\circ} \mathbf{C}\right)$ & Time (min) & $\begin{array}{c}\text { Char (wt } \\
\text { \%) }\end{array}$ & Liquid (wt \%) & $\begin{array}{c}\text { Gas (wt } \\
\text { \%) }\end{array}$ \\
\hline S1 & 400 & 10 & 33.28 & 26.62 & 40.10 \\
S2 & 400 & 20 & 33.39 & 27.63 & 38.98 \\
S3 & 400 & 30 & 33.41 & 32.20 & 34.40 \\
S4 & 450 & 10 & 37.63 & 20.94 & 41.43 \\
S5 & 450 & 20 & 38.24 & 24.91 & 36.86 \\
S6 & 450 & 30 & 33.85 & 30.03 & 36.12 \\
\hline
\end{tabular}

The effect of temperature change was proven when the thermal heating level increased to $450^{\circ} \mathrm{C}$, the liquid yield decreased while the gas yield increased. Operating conditions at high temperatures cause larger molecules such as liquids to split to produce gas. This is consistent with previous research [27]. The effect of residence time was proven when residence time increased to 30 minutes, liquid yield increased while char and gas yield decreased. This is consistent with previous research [13]. Low temperatures and long 
residence times support char production, while higher temperatures and short residence times result in high liquid product production [28].

\subsection{Total Phenolic Content (TPC)}

The TPC was determined from linear equation of gallic acid calibration curve with the specific at Fig. 2 was expressed in microgram which equals to gallic acid per milligram sample ( $\mu \mathrm{g} \mathrm{GAE} / \mathrm{mg}$ ). Absorbance of mixtures containing gallic acid, Folin Ciocalteu and sodium carbonate increases proportionately with increasing concentrations of gallic acid [29]. The calculation results of TPC S1 to S6 are shown on Table 2.

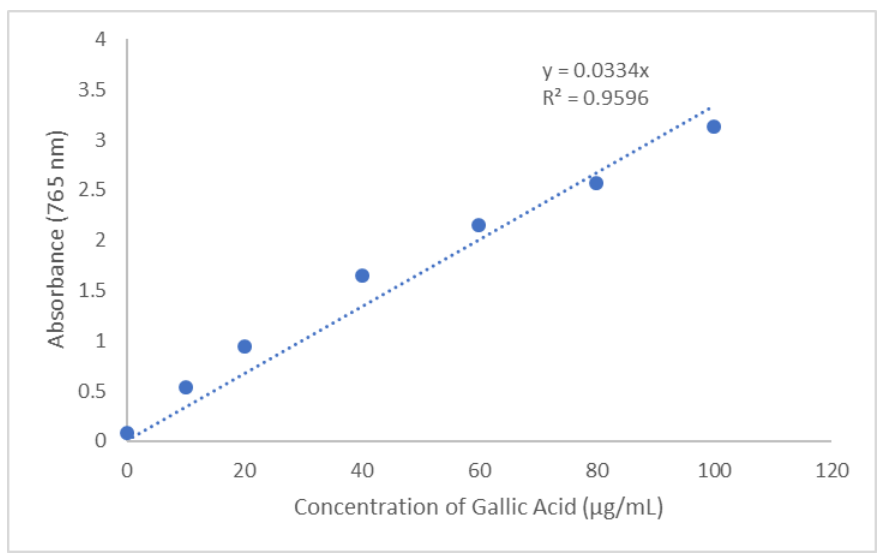

Fig. 2. Gallic acid calibration curve

Table 2. TPC of PA extracts

\begin{tabular}{lcccccc}
\hline Symbol & S1 & S2 & S3 & S4 & S5 & S6 \\
\hline PA $(\mathrm{g})$ & 26.62 & 27.63 & 32.20 & 20.94 & 24.91 & 30.03 \\
TPC $($ mg GAE/g) & 85.03 & 96.41 & 112.13 & 72.90 & 90.87 & 111.68 \\
\hline
\end{tabular}

In this work, the highest TPC of $112.13 \mathrm{mg} \mathrm{GAE} / \mathrm{g}$ was observed in S3 under MAP operating conditions at $400^{\circ} \mathrm{C}$ for 30 minutes. Because phenolic compounds are not decomposed in low temperature conditions. Furthermore, some phenolic compounds that dissolve in water are extracted into water in lower temperature conditions due to low evaporation of water [4]. The phenolic structure can be maintained at lower temperatures under lower vapor pressure in the reactor because some phenols are primary pyrolysis products and are produced mainly by cracking $\beta-\mathrm{O}-4$ aryl ether bonds in lignin [30]. Previous studies reported that TPC in PA extract of pineapple biomass was $2.67 \pm 0.14 \mathrm{mg}$ GAE [22] and palm kernel shell was $49.96 \mathrm{mg} \mathrm{GAE} / \mathrm{g}$ [29]. This shows that TPC in CS is greater than pineapple biomass and palm kernel shell.

\subsection{Antibacterial Activity}

Six samples of phenolic extract from coconut shell (PECS) were tested for their antibacterial activities at the Central Laboratory for Health and Medical Apparatus Testing in Central Java. The results are shown in Fig. 3. 


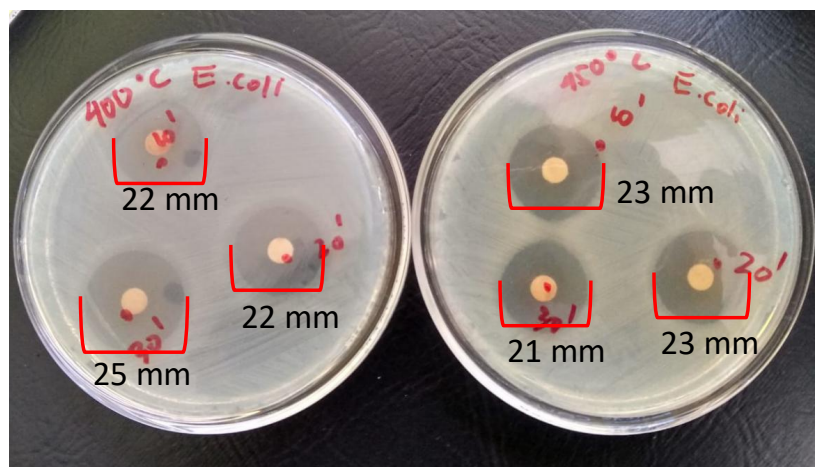

Fig. 3. Antibacterial activity of PECS on inhibition of Escherichia coli

According to Davis dan Scout [31], anti-bacterial activity in the clear zone test is divided into the following: the diameter of zone of inhibition which is less than $5 \mathrm{~mm}$ is categorized as weak, zone of inhibition of $5-10 \mathrm{~mm}$ is categorized as medium, zone of inhibition of $10-20 \mathrm{~mm}$ is categorized as strong, and zone of inhibition more than $20 \mathrm{~mm}$ is categorized as very strong. The test results showed the antibacterial activity of each sample of coconut shell phenolic compounds was very strong. Samples that had the largest zone of inhibition diameter were at S3 $(25 \mathrm{~mm})$ with MAP $400^{\circ} \mathrm{C}$ operating conditions for 30 minutes. The diameter of inhibition zone can be influenced by TPC concentration. The higher concentration leads to the higher antibacterial activity [32]. The reduction of important organic ions that enter the cell results in inhibited growth to death of the cell [33]. Damage to the bacterial cell wall results in decreased permeability of the cytoplasmic membrane to transfer important ions needed by bacteria. The high phenolic compounds in PECS can denature proteins contained in bacterial cell walls so that the inhibitory ability of PECS can act as an antibacterial agent.

\section{CONCLUSION}

From this study, MAP of CS samples under different operating conditions showed the highest liquid product acquisition at $400^{\circ} \mathrm{C}$ with residence time of 30 minutes. Based on the TPC test of PA extract (PECS), PA from MAP with this condition has the highest concentration of $112.13 \mathrm{mg} \mathrm{GAE} / \mathrm{g}$ and shows the largest bacterial growth zone of inhibition, which is $25 \mathrm{~mm}$. However, more studies must be carried out prior to any commercialization attempts for this compound.

\section{ACKNOWLEDGEMENT}

Financial support from the Student Creativity Program 2019 (the Ministry of Research and Higher Education of Republic Indonesia) and the facility from the Institute of Bioproduct Development, University Technology Malaysia are acknowledged. 


\section{REFERENCES}

[1] R. Zikria, Outlook Komoditi Kelapa, Jakarta: Sekretariat Jendral Kementerian Pertanian, ISSN: 1907-1507 (2014)

[2] Direktorat Jendral Perkebunan, "Kelapa," in Statistik Perkebunan Indonesia 20172019, Jakarta, 1-82 (2018)

[3] R. Barlina, E. Manaroinsong, and J. Wungkana, Bul. Palma, 18(2), 63-71 (2018)

[4] C. Ma, W. Li, Y. Zu, L. Yang, and J. Li, Molecules, 19, 20821-20838 (2014)

[5] D. Bilehal, L. Li, and Y. H. Kim, Food Anal. Methods, 5(1), 109-112 (2012)

[6] A. S. Pimenta, M. Fasciotti, T. V. C. Monteiro, and K. M. G. Lima, Molecules, 23(2), 1-12 (2018)

[7] D. S. Fardhyanti, A. Damayanti, and A. Larasati, Karakterisasi Bio-Oil dari Hasil Pirolisis terhadap Biomasa, in Prosiding Seminar Nasional Teknik Kimia "Kejuangan", 13 April 2017, Yogyakarta, Indonesia (2017)

[8] E. Kuoppala, K. Tiilikkala, and A. Oasmaa, Energy \& Fuels, 26, 1275-1283 (2012)

[9] T. Kan, V. Strezov, and T. J. Evans, Renew. Sustain. Energy Rev., 57, 1126-1140 (2016)

[10] E. Graciosa, M. Arêdes, R. Pecenka, A. De Cássia, and O. Carneiro, Renew. Sustain. Energy Rev., 75, 592-600 (2017)

[11] A. V. Bridgwater, P. Carson, and M. Coulson, Int. J. Glob. Energy Issues, 27(2), 204-216 (2007)

[12] O. Senneca, F. Cerciello, S. Heuer, and P. Ammendola, Fuel, 225, 419-425 (2018)

[13] Z. Rabiu and Z. A. Zakaria, J. Appl. Environ. Biol. Sci., 7(2S), 59-62 (2017)

[14] C. Ma, K. Song, J. Yu, L. Yang, C. Zhao, W. Wang, G. Zu, and Y. Zu, J. Anal. Appl. Pyrolysis, 104, 38-47 (2013)

[15] D. L. Nugrahaini, E. Kusdiyantini, U. Tarwotjo, and A. H. Prianto, Bioma Berk. Ilm. Biol., 19(1), 30-37 (2017)

[16] K. Ridhuan, D. Irawan, and R. Inthifawzi, Turbo J. Progr. Stud. Tek. Mesin, 8(1), 69-78 (2019)

[17] M. A. Hossain, J. Jewaratnam, P. Ganesan, J. N. Sahu, S. Ramesh, and S. C. Poh, Energy Convers. Manag., 115, 232-243 (2016)

[18] F. Z. Abas, F. N. Ani, and Z. A. Zakaria, J. Clean. Prod., 2018, doi: 10.1016/j.jclepro.2018.02.052.

[19] S. J. Ariffin, M. Yahayu, H. El-Enshasy, R. A. Malek, A. A. Aziz, N. M. Hashim, and Z. A. Zakaria, Indian J. Exp. Biol., 55, 427-435 (2017)

[20] F. Mushtaq, T. A. T. Abdullah, R. Mat, and F. N. Ani, Bioresour. Technol., 442450 (2015), doi: 10.1016/j.biortech.2015.02.055.

[21] R. Omar, A. Idris, R. Yunus, K. Khalid, and M. I. A. Isma, Fuel, 90(4), 1536-1544 (2011)

[22] S. Mathew, Z. A. Zakaria, and N. F. Musa, Process Biochem., 50(11), 1985-1992 (2015)

[23] F. Z. Abas, Z. A. Zakaria, and F. N. Ani, J. Appl. Pharm. Sci., 8(7), 65-71 (2018)

[24] T. Haeldermans, J. Claesen, J. Maggen, R. Carleer, J. Yperman, P. Adriaensens, P. Samyn, D. Vandamme, A. Cuypers, K. Vanreppelen, and S. Schreurs, J. Anal. Appl. Pyrolysis, 138, 218-230 (2019) 
[25] A. Y. Loo, K. Jain, and I. Darah, Food Chem., 107, 1151-1160 (2008)

[26] M. I. S. Abdelhady, A. A. Motaal, and L. Beerhues, Am. J. Plant Sci., 2(6), 847850 (2011)

[27] S. Mutsengerere, C. H. Chihobo, D. Musademba, and I. Nhapi, Renew. Sustain. Energy Rev., 104, 328-336 (2019)

[28] J. B. G. Souza, N. Ré-Poppi, and J. L. Raposo, J. Braz. Chem. Soc., 23(4), 610-617 (2012)

[29] R. S. R. Sulong, S. E. Zulkifli, R. Hasham, and Z. A. Zakaria, J. Phys. Conf. Ser., $1444(2020)$

[30] C. Amen-Chen, H. Pakdel, and C. Roy, Bioresour. Technol., 79(3), 277-299 (2001)

[31] W. W. Davis and T. R. Stout, Appl. Microbiol., 22(4), 659-665 (1971)

[32] O. Franchi, L. Cabrol, R. Chamy, and F. Rosenkranz, J. Biotechnol., 310, 40-48 (2020)

[33] T. I. Purwantiningsih, Y. Y. Suranindyah, and Widodo, Bul. Peternak., 38(1), 59-64 (2014) 